\title{
Seasonal habitat and length influence on the trophic niche of co-occurring tropical tunas in the eastern Atlantic Ocean
}

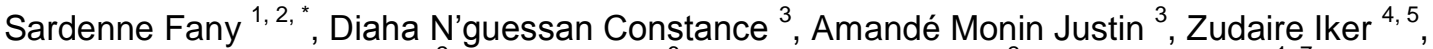 \\ Couturier Lydie I. E. ${ }^{2}$, Metral Luisa ${ }^{6}$, Le Grand Fabienne ${ }^{2}$, Bodin Nathalie ${ }^{1,7}$
}

\footnotetext{
${ }^{1}$ Research Institute for Sustainable Development (IRD), UMR MARBEC IRD/CNRS/Ifremer/UM, Centre de Recherche Halieutique, Sète, France

${ }^{2}$ University of Western Brittany (UBO), UMR LEMAR CNRS/UBO/IRD/Ifremer, Brest, France

${ }^{3}$ Centre de Recherches Océanologiques , Abidjan, Côte d'Ivoire

4 Institut de recherche pour le developpement France-Sud, 98751, UMR MARBEC, Sète, France

${ }^{5}$ IKERBASQUE, Basque Foundation for Science, Bilbao, Spain

${ }^{6}$ IFREMER, UMR MARBEC IRD/CNRS/Ifremer/UM, Centre de Recherche Halieutique, Sète, France

${ }^{7}$ Seychelles Fishing Authority, 280177, Victoria, Mahe, Seychelles

*Corresponding author : Fany Sardenne, email address : fany.sardenne@hotmail.fr
}

\begin{abstract}
:
In the Gulf of Guinea, bigeye Thunnus obesus (BET) and yellowfin tuna Thunnus albacares (YFT) are important for commercial fisheries and play a prominent ecological role as top predators. Using fatty acid profiles and carbon and nitrogen stable isotopes we examined their niche partitioning in this understudied region. Niche overlap was high ( $>70 \%)$, similar to percentages in other ocean basins. BET occupied a higher trophic position than YFT and fed on deeper prey (high $\delta 15 \mathrm{~N}$ values and high proportions of mono-unsaturated fatty acids). The trophic position of YFT decreased slightly in the last 15 years $(\delta 15 \mathrm{~N}$ values decrease $\sim 0.5 \%$ ) suggesting a change in epipelagic communities, as observed in the eastern Pacific Ocean. Ontogenic changes were limited to BET. For both species, the dietary proportion of the diatoms marker $(20: 5 n-3)$ increased in the seasonal upwelling area, highlighting the seasonal habitat influence on tunas diet. The relatively lipid-rich muscle ( $6 \%$ dry weight) of Atlantic tropical tunas suggested a richer diet in this region than for Indian Ocean tropical tunas and/or differences in energy allocation strategies.
\end{abstract}

Keywords : niche overlap, fatty acids, stable isotopes, body condition, pelagic predators 


\section{INTRODUCTION}

Bigeye Thunnus obesus (BET) and yellowfin tuna Thunnus albacares (YFT) are oceanic predators co-occurring in tropical waters worldwide. In the eastern Atlantic Ocean, around 200000 tons of BET and YFT are caught each year, leading to an overexploitation of these species (ICCAT 2015). Tunas occupy high trophic positions in pelagic habitats and their biomass reduction induced by fishing raises concerns about the health of both tuna populations and pelagic ecosystems, especially in a global change context (Chust et al. 2014, Duffy et al. 2017, Hobday et al. 2017). This is a topical issue within the Gulf of Guinea, a productive ecosystem that supports complex food webs, which has been subject to increased pressure from commercial fisheries, human population growth and pollution from domestic and industrial sources in the adjacent countries (Aryeetey 2002, Ukwe et al. 2006).

Information on the trophic ecology of tuna in the Gulf of Guinea is limited, especially those relating to ecological tracers (Olson et al. 2016). Ecological tracers are biochemically stable compounds within organisms, including stable isotopes (SI) of carbon and nitrogen and fatty acids (FA). They provide time-integrated information on food assimilated in consumers' tissues (Ramos and González-Solís 2012) over a period of several weeks to years in fish (Iverson et al. 2004, Madigan et al. 2012). Predictable increase from prey to predator in the nitrogen isotope ratio $\left({ }^{15} \mathrm{~N} /{ }^{14} \mathrm{~N}\right.$ expressed as $\delta^{15} \mathrm{~N}$ values $)$ allows the determination of trophic position (Vander Zanden et al. 1997). Changes in the carbon isotope ratio $\left({ }^{13} \mathrm{C} /{ }^{12} \mathrm{C}\right.$ expressed as $\delta^{13} \mathrm{C}$ values) are linked to modifications of the forage habitat (i.e., coastal vs. open ocean) (France 1995). FA are lipid constituents necessary for physiological functions, some of which cannot be readily synthesized by all consumers and are transferred conservatively in food webs. Some 'essential' FA, such as docosahexaenoic acid (22:6n-3), eicosapentaenoic acid (20:5n-3) and arachidonic acid (20:4n-6) are best preserved during trophic transfer (Tocher 2003). The profile of the FA transferred from prey to predator may inform on the forage taxa 
57 (Dalsgaard et al. 2003, Budge et al. 2012). For example, in the pelagic environment, 22:6n-3

58 is generally a marker for dinoflagellates, 20:5n-3 is a marker for diatoms (Dalsgaard et al.

59 2003) and 18:1n-9 is a marker for deep-copepods (Teuber et al. 2014). In the highest trophic

60 levels, transferred FA are better preserved in storage lipids than in structural lipids (Robin et

61 al. 2003, Budge et al. 2012). The quantification of these ecological tracers also allows the

62 estimation of feeding niche extent (niche space) and provides insights into resource

63 partitioning (niche overlap) between co-occurring species (Jackson et al. 2011, Layman et al.

64 2012) including tunas (Teffer et al. 2015, Sardenne et al. 2016).

65 Given their bioenergetics (i.e. regional heterotherms, fast swim), tunas have adapted a 66 generalist foraging strategy in oligotrophic waters worldwide, consuming small fishes, 67 crustaceans, and cephalopods (Olson et al. 2016). In the eastern Atlantic Ocean, more than 68160 prey taxa have been identified in their stomach content (Dragovich 1970, Dragovich and 69 Potthoff 1972) indicating that diet variability is linked to environmental conditions (e.g. sea 70 surface temperature and mixed-layer depth) (Weng et al. 2009, Parrish et al. 2015, Duffy et al. 71 2017). In the Atlantic Ocean, tropical tunas take advantage of prey aggregations, such as the 72 mesopelagics lightfish Vinciguerria nimbaria (Ménard and Marchal 2003) and the cigarfish Cubiceps pauciradiatus (Ménard et al. 2000, Bard et al. 2002). The different tuna species share a common habitat and often form schools, but BET feeds more on vertically migrating Ommastrephidae squids than YFT (Cherel et al. 2007, Young et al. 2010b, Logan and Lutcavage 2013). Resource partitioning between BET and YFT is however not quantified for tuna populations from the eastern Atlantic. Olson et al. (2016) provided the first bulk isotopic values for tropical tunas in this area, suggesting a slightly higher trophic level of BET compared to other species (i.e., $\delta^{15} \mathrm{~N}$ of $12.7 \pm 0.9 \%$ for BET and of $12.2 \pm 1.0 \%$ for YFT, between 2000 and 2004). They suggested that these values were affected by a size sampling bias or unaccounted for habitat effects. 
82 To build upon this research, we aimed to (i) determine whether seasonal upwelling, length 83 and sex (male vs. female) have an effect on BET and YFT diet using SI and FA; and (ii) quantify feeding niches and partitioning of tunas (i.e. niches extent and overlap).

\section{MATERIAL \& METHODS}

\subsection{Tunas and tissue sampling}

BET and YFT were caught by purse-seiners operating in the Gulf of Guinea, eastern equatorial Atlantic Ocean, between July 2013 and September 2014. Samples were collected at the landing site (fishing port for BET and "Pêche et froid" cannery for YFT) in Abidjan Port, Ivory Coast (Fig. 1). Fishing dates (Julian days) and coordinates of fishing locations were recovered from vessel logbooks, corresponding to the catch location or catch estimates. Catch estimates are mean data computed from logbooks when anglers have grouped fish from several fishing activities in the brine freezing wells of purse-seiners (maximum uncertainty of 33 days and $7.4^{\circ}$ square). Catch dates covered July-September and January-February, i.e. seasonal upwelling and non-upwelling periods, respectively. Fork length (FL measured with calliper to the nearest $0.1 \mathrm{~cm}$ ), sex and macroscopic identification of gonad maturity (visual examination according to Diaha et al. 2016) were determined for each fish. Forty-five BET (22 females, 23 males) and 50 YFT (19 females, 31 males) were selected. Length ranges were 111.3 $\pm 25.8 \mathrm{~cm}$ FL for BET and $124.6 \pm 22.6 \mathrm{~cm}$ FL for YFT and included only developing fish (male and female of gonad macroscopic stage 1-2) as tunas diet may change during the spawning process (Zudaire et al. 2015). Around $2 \mathrm{~g}$ of front dorsal white muscle tissue and liver were sampled on each fish and stored frozen prior to analyses $\left(-20^{\circ} \mathrm{C}\right.$ during four months after sampling then $-80^{\circ} \mathrm{C}$ for two years).

\subsection{Ecological tracers analysis}

SI analyses were performed on white muscle, the less variable tissue and the most extensively used in fish ecology (Pinnegar and Polunin 1999), while FA profiles were examined from 
107 liver tissue, the richest tissue in storage lipids in tropical tunas (Sardenne et al. 2017). In

108 addition, we recorded the muscle lipid content as a proxy of fish body condition (Tocher 109 2003), thereafter included in the term 'ecological tracers'.

\subsubsection{Stable isotope analysis and lipid content determination}

Carbon and nitrogen SI and lipid content were analyzed on 92 freeze-dried muscle samples of tunas (45 BET and 47 YFT, three YFT samples have been lost during lab analysis). Samples were ground up to a fine homogeneous powder with a ball mill MM200 (Retsch). They were then treated with dichloromethane using a Dionex Accelerated Solvent Extractor (ASE 200), as described by Bodin et al. (2009) to remove naturally ${ }^{13} \mathrm{C}$-depleted lipids that affect $\delta^{13} \mathrm{C}$ values (Sardenne et al. 2015). Lipid extracts were dried to a constant weight and weighed to the nearest $0.1 \mathrm{mg}$ to determine total lipid content (TLC, in \% of dry weight (dw) sample). Lipid-free powders were analyzed for SI using an Elemental Analyser (Flash EA 1112; Thermo Scientific) coupled to an Isotope Ratio Mass Spectrometer (Delta V Advantage with a Conflo IV interface; Thermo Scientific) at the LIENSs Stable Isotope facility (La Rochelle, France). Results were reported in the $\delta$ unit notation and expressed as parts per thousand (\%o) relative to international standards (atmospheric $\mathrm{N}_{2}$ for nitrogen and Vienna-Pee Dee Belemnite for carbon). Calibration was completed using reference materials (IAEA- $\mathrm{N}_{2},-\mathrm{NO}_{3}^{-}$, -600 for nitrogen; USGS-24, IAEA-CHE, -600 for carbon). Analytical precision based on replicate measurements of internal laboratory standard (acetanilide, Thermo Scientific) was $<0.15 \%$ for both $\delta^{15} \mathrm{~N}$ and $\delta^{13} \mathrm{C}$. The effectiveness of the chemical extraction of the lipid-free samples was checked by examining the $\mathrm{C}: \mathrm{N}$ ratio from the percent element weight $(\mathrm{C}: \mathrm{N}<$ 3.5; Post et al. 2007).

\subsubsection{Fatty acid analysis}

FA were determined on total lipid extracts of fresh liver samples (45 BET and 50 YFT). Around $165 \pm 35 \mathrm{mg}$ of tissue were extracted using a mixture of dichloromethane and methanol 
$132(2: 1, \mathrm{v} / \mathrm{v})$ with a potter homogenizer (glass/teflon). A known amount of 23:0 fatty acid was

133 added as an internal standard, and extracts were then trans-esterified with sulphuric acid $134\left(3.8 \%\right.$ in methanol) at $100^{\circ} \mathrm{C}$ for $10 \mathrm{~min}$. After addition of $800 \mu \mathrm{L}$ of hexane and three 135 washes with hexane-saturated distilled water, the fatty acid methyl esters (FAME) were 136 separated and quantified on a Varian CP8400 gas chromatography equipped with a Zebron 137 ZB-WAX column (30 $\mathrm{m}$ in length, $0.25 \mathrm{~mm}$ internal diameter, $0.25 \mu \mathrm{m}$ film thickness; 138 Phenomenex) and a flame ionisation detector at the LEMAR Lipidocean facility (Brest, 139 France). Samples were injected in splitless mode at $280^{\circ} \mathrm{C}$ and carried by hydrogen gas. The 140 oven temperature was raised from $60^{\circ} \mathrm{C}$ to $150{ }^{\circ} \mathrm{C}$ at $50^{\circ} \mathrm{C} / \mathrm{min}$, to $170{ }^{\circ} \mathrm{C}$ at $3.5^{\circ} \mathrm{C} / \mathrm{min}$, to $141185{ }^{\circ} \mathrm{C}$ at $1.5{ }^{\circ} \mathrm{C} / \mathrm{min}$, to $225{ }^{\circ} \mathrm{C}$ at $2.4{ }^{\circ} \mathrm{C} / \mathrm{min}$ and then to $250^{\circ} \mathrm{C}$ at $5.5^{\circ} \mathrm{C} / \mathrm{min}$.. FAMEs were 142 identified by comparing sample retention times to those of a commercial standard mixture 143 (37-components FAME Mix; Sigma) and lab-made standards using Galaxie 1.9.3.2 software 144 (Varian). Individual FA results were expressed as percentage of the total identified FA. 145 Finally, only FA accounting for $>1 \%$ in at least two samples $(n=20)$ were kept for statistical 146 analyses (Table 1).

\subsection{Data analysis}

We used linear regressions or multivariate analyses to examine the relative importance of spatiotemporal (fishing longitude and date) and biological variables (species, length, and sex) on ecological tracers $\left(\delta^{15} \mathrm{~N}\right.$ and $\delta^{13} \mathrm{C}$, TLC and FA profile). There was no collinearity among the five factors (variance inflation factors ranking 1.1 to 4.3 ). We added to our models the interaction of species*length interaction to detect inter-specific differences in diet shift. For isotopic data and TLC, covariate selection was based on the Akaïke Information Criterion (AIC). ANOVA on multiple regressions and post-hoc t-tests (with t the test value) were then applied on scaled data, and normality of the residuals checked on Q-Q plots (based on the Q- 
157 data, we tested for the equality of variances (using the function Betadisper, an analogous to

158 Levene's test available in the $\mathrm{R}$ package vegan). We then used Permutational multivariate 159 analysis of variance (PERMANOVA; non-parametric) based on the Bray-Curtis distance 160 matrix of the untransformed \% FA to test the effect of candidate variables. Untransformed \% 161 FA were used to avoid giving artificial weight to FA present in small quantities (Kelly and 162 Scheibling 2012). Differences in individual FA were assessed using Wilcoxon's tests (with W 163 the test value) for categorical variables (i.e., species and sex) and linear regressions for 164 continuous ones (i.e., longitude, date, and length).

165 Then, we compared tunas' feeding niches using the $\mathrm{R}$ package SIBER (Stable Isotope 166 Bayesian Ellipses in R) (Jackson et al. 2011) on biplots of $\delta^{13} \mathrm{C}$ and $\delta^{15} \mathrm{~N}$ values and of 167 individual coordinates from dimension 1 and 2 of the principal components analysis (PCA) 168 for the untransformed \% FA. For each species, we computed standard ellipses encompassing $16995 \%$ of the data and calculated the Bayesian standard ellipse areas $\left(\mathrm{SEA}_{\mathrm{B}}\right)$ and their credible 170 intervals $(50 \%, 75 \%$ and $95 \%)$. The $\mathrm{SEA}_{\mathrm{B}}$ is used as a proxy of the extent of the feeding 171 niche, parallel to the isotopic niche of Layman et al. (2012) and the credible intervals 172 represent the uncertainty surrounding the metric. The $\mathrm{SEA}_{\mathrm{B}}$ quantifies the feeding niche 173 occupied by each species (i.e., intra-specific) while the overlap between $S_{B} A_{B}$ quantify the 174 feeding niche share by the two species (i.e., inter-specific). We computed a Bayesian estimate 175 for the overlap between the two $\mathrm{SEA}_{\mathrm{B}}$ and an overlap coefficient (OC, express in \%) to 176 quantify the proportion of feeding niche overlap. OC is the ratio between the Bayesian 177 estimates for the overlap and the minimal $\mathrm{SEA}_{\mathrm{B}}$ filled by a species (similar to the Jaccard 178 similarity coefficient). OC of $0 \%$ corresponds to no overlap and of $100 \%$ to a full SEA 179 overlap. All statistical analyses were performed with R 3.0.2 software.

\subsection{Inter- and intra-specific variability of ecological tracers}


Muscle $\delta^{15} \mathrm{~N}$ values were more variable than $\delta^{13} \mathrm{C}$ values for both species $\left(\mathrm{BET} \delta^{15} \mathrm{~N}\right.$ : $\min -\max =11.6-14.2 \%$, Coefficient of variation $\mathrm{CV}=5.0 \% ; \delta^{13} \mathrm{C}:-17.6--16.5 \%$; $C V=1.1 \%$ and YFT $\delta^{15} \mathrm{~N}: 10.1-13.2 \%, \mathrm{CV}=7.8 \% ; \delta^{13} \mathrm{C}:-17.8-16.4 \%$; $\left.\mathrm{CV}=1.7 \%\right)$. The total lipid content in muscle showed large variations in BET $(1.6-36.2 \% \mathrm{dw}, \mathrm{CV}=123 \%)$ and YFT $(0.5-18.2 \% \mathrm{dw}, \mathrm{CV}=82.6 \%)$. In liver tissue, the three most abundant FA in both BET and YFT were the saturated FA (SFA) 16:0 (BET: 17.4-31.7\%; YFT: 18.0-32.4\%), the polyunsaturated FA (PUFA) 22:6n-3 (BET: 15.9-29.8\%; YFT: 12.9-32.0\%) and the monounsaturated FA (MUFA) 18:1n-9 (BET: 6.9-25.4 \%; YFT: 4.4-24.2\%). Majors FA in the two species also included PUFA 20:5n-3 (BET: 3.3-8.8 \%; YFT: 3.4-10.4\%) and 20:4n-6 (BET: 2.3-8.3 \%; YFT: 2.0-6.7 \%); MUFA 18:1n-7 (BET: 0.8-4.1\%; YFT: $1.2-4.0 \%$ ) and 16:1n-7 (BET: 1.2-4.1\%; YFT: 1.1-3.8\%); SFA 18:0 (BET: 6.1-11.7\%; YFT: 7.9-13.9\%) and 17:0 (BET: 1.5-3.0\%; YFT: 1.0-2.0\%). Overall, elevated proportions of PUFA n-3 (>30 \%) compared to PUFA n-6 (<10\%) were found for both species (Table 1).

'Species' and to a lesser extent 'length' had the largest influence on the ecological tracers, especially on $\delta^{15} \mathrm{~N}$ values, TLC and FA profiles (highest F and Pseudo-F; Table 2). The spatiotemporal variables 'longitude' affected only FA while 'fishing date' has no influence on ecological tracers. First, inter-specific differences were noted with higher $\delta^{15} \mathrm{~N}$ values in BET than YFT (mean $\pm \mathrm{SD}=12.8 \pm 0.7 \%$ ov. $11.7 \pm 0.9 \%$; $\mathrm{t}=-7.8, \mathrm{p}<0.001)$ while a larger intra-specific variability was found in YFT's values $(\mathrm{CV}=5 \%$ for BET vs. $8 \%$ for YFT). TLC was also higher for BET $(\mathrm{t}=2.0, \mathrm{p}<0.05)$ despite a larger intra-specific variability $(\mathrm{CV}=133 \%$ for BET vs. $83 \%$ for YFT). Overall, FA profiles and levels of several individual FA were generally different between species (Pseudo-F $=10.5, p<0.001$ and Table 1). Main differences concerned 18:1n-9 (ca. $14 \pm 5 \%$ for BET $v s .11 \pm 6 \%$ for YFT), 18:0 (ca. $9 \pm 1 \%$ for BET $v s .11 \pm 2 \%$ for YFT) and 20:4n-6 (ca. $5 \pm 2 \%$ for BET $v s .4 \pm 1 \%$ for YFT). In contrast, no inter-specific differences were observed for the two other essential FA, 
207 i.e. $22: 6 n-3(\mathrm{~W}=873, \mathrm{p}=0.06)$ and 20:5n-3 $(\mathrm{W}=1090, \mathrm{p}=0.80)$. Regarding the main FA 208 classes, SFA were in higher proportions in YFT than BET (ca. 39 $\pm 3 \%$ vs. 36 $\pm 5 \%$; W $=662$, $209 \mathrm{p}<0.001$ ), MUFA were higher in BET than YFT (ca. $23 \pm 6 \%$ vs. $18 \pm 7 \%$; W $=1625, \mathrm{p}<$ $2100.001)$ and no difference was observed for PUFA $(40 \pm 6 \% ; \mathrm{W}=882, \mathrm{p}=0.07)$ (Table 1$)$.

211 Second, BET length explained $33 \%$ and $19 \%$ of the variance in $\delta^{15} \mathrm{~N}$ values and TLC, 212 respectively. The $\delta^{15} \mathrm{~N}$ values linearly increased with length in BET from $12.7 \pm 0.4 \%$ under $21380 \mathrm{~cm}$ to $13.5 \pm 0.3 \%$ above $130 \mathrm{~cm}$ but no significant increase was observed for YFT (Fig. 214 2a). TLC and its intra-specific variability also increased with length in BET, from $2.5 \pm 0.8 \%$ $215 \mathrm{dw}(\mathrm{CV}=30 \%)$ for individuals under $80 \mathrm{~cm}$ to $13.1 \pm 12.6 \% \mathrm{dw}(\mathrm{CV}=96 \%)$ above $130 \mathrm{~cm}$, 216 while it remained constant in YFT (around 4.5 $\pm 3.7 \%$ dw; Fig. 2c). Length influenced FA 217 profiles (PERMANOVA, Pseudo-F $=5, \mathrm{p}<0.05$ ) for both species, but results were different 218 for each individual FA and generally unclear because of large variability within species. For 219 example, the proportion of essential n-3 PUFA 20:5n-3 increased with length in BET, from $2205.0 \pm 1.5 \%$ of total FA under $80 \mathrm{~cm}$ to $7.7 \pm 1.2 \%$ above $130 \mathrm{~cm}$ but remained constant in YFT $221(6.2 \pm 1.6 \% ; C V=26 \%)$ (Fig. 3a). In contrast, the proportion of essential n-6 PUFA 20:4n-6 222 tended to decrease with length in both species, from $4.9 \pm 1.5 \%$ under $80 \mathrm{~cm}$ to $3.9 \pm 1.1 \%$ 223 above $130 \mathrm{~cm}\left(\right.$ mean \pm SD for the two species) but the relationship was poor $\left(\mathrm{r}^{2}=0.12\right)$ 224 (Fig. 3b). For some other important FA trophic markers, such as 22:6n-3 and 18:1n-9, no 225 relationship with 'length' was detected (Fig. 3c and 3d).

226 Finally, longitude influenced the FA profiles (Table 2). The addition of 'longitude' as an 227 illustrative variable on PCA indicated an increasing proportion of 20:5n-3, 20:4n-3 and 18:2n2286 and a decreasing proportion of 20:4n-6 in tunas' liver with the longitude value. Between $22917.6^{\circ} \mathrm{W}$ and $4^{\circ} \mathrm{E}$, the proportion of $20: 5 \mathrm{n}-3$ increased similarly in both species from $5.2 \pm 0.8 \%$ 230 to $6.7 \pm 1.6 \%($ mean $\pm \mathrm{SD}$ for the two species; Fig. 4a) and the $20: 4 \mathrm{n}-3$ proportion increased 231 from $0.3 \pm 0.1 \%$ to $0.2 \pm 0.6 \%$ (Fig $4 \mathrm{~b}$ ). Within this longitude range, the increase of the $18: 2 \mathrm{n}-6$ 
232 proportion was more restricted (mean ranging from 0.8 to $1 \% ; \mathrm{p}<0.05, \mathrm{r}^{2}=0.06$ ). A large

233 decrease in the 20:4n-6 proportion was observed in BET only, (mean ranging from $6.7 \%$ to $2343.8 \% ; \mathrm{p}<0.001, \mathrm{r}^{2}=0.28$; Fig. $4 \mathrm{~b}$ ). Carbon isotopic values were unaffected by the five tested 235 factors (Table 2). Fish 'sex' affected only TLC, females being leaner than males $(4.6 \pm 5.5 \%$ 236 vs. $7.1 \pm 8.0 \% ; \mathrm{t}=2.7, \mathrm{p}<0.01)$. 'Fishing date' had no effect on any of the ecological tracers 237 analyzed.

\subsection{Comparison of tropical tuna feeding niches}

First, feeding niches of BET and YFT mostly overlapped according to both isotopic and FA data. Despite the slightly higher $\delta^{15} \mathrm{~N}$ values of BET, the isotopic feeding niches of the two species overlapped of $\mathrm{OC}=76.8 \pm 13.7 \%$ (Fig. 5a). This result was in accordance with FA feeding niches of the species, that also had an important overlap ( $\mathrm{OC}=70.2 \pm 8.2 \%$; Fig. 5b). FA feeding niches were only discriminated on the PCA-Dimension 2 which explained $21.3 \%$ of the total variability in FA profiles, and was mainly driven by $20: 5 n-3$ and by minors FA such $24: 1 n-9,17: 0$ 18:2n-6 and 22:4n-6 and to a lesser extent by 20:1n-9 and 18:1n-9 (Fig. $5 b)$. Second, the extent of tuna feeding niches (proxy of the intra-specific variability) varied across tracers. The isotopic niche extent was smaller for BET than for YFT $(\mathrm{t}=-192, \mathrm{p}<0.001$ with all posterior estimates smaller for BET than for YFT; Fig. 5a) while the FA niche extent was larger for BET than for YFT $(\mathrm{t}=74, \mathrm{p}<0.001$ with $89 \%$ of the posterior estimates larger for BET than for YFT; Fig. 5b). Finally, the variability in FA profiles was mainly explained by individual variability among all fish rather than the difference between species $(31.1 \%$ of the explained variability was observed on PCA-Dimension 1 while the two species were discriminated on the PCA-Dimension 2; Fig. 5b).

\section{DISCUSSION}

Using SI and FA ecological tracers, we quantified for the first time the feeding niches of BET and YFT and their overlap in the eastern Atlantic Ocean. Overall, there was a large overlap in 
257 the feeding niches of tropical tunas, despite BET occupying a slightly higher trophic position

258 (higher $\delta^{15} \mathrm{~N}$ values). The fish length appeared to be the most influencing factor for ecological 259 tracers in BET. Spatiotemporal variables had no influence on SI values, while higher 260 proportions of diatoms' FA marker (20:5n-3) were observed in the liver tissue of tunas caught 261 beyond $5^{\circ} \mathrm{E}$ during the seasonal upwelling. Essential FA such as $20: 5 n-3$ could therefore be 262 interesting tracers for the monitoring of tuna's trophic ecology over large spatial scales. Large 263 datasets of SI and FA should allow future studies to consider the effect of other biological and 264 environmental factors (e.g. tuna maturity, sea surface temperature, oxygen conditions) and 265 their interactions that we could not integrate here.

\subsection{Trophic position of yellowfin decreases in the Atlantic Ocean}

267 Spatial changes in baseline nitrogen composition preclude any direct comparison of tuna 268 isotopic values among oceans (Lorrain et al. 2015). In the Indian and Pacific Oceans, the 269 baseline $\delta^{15} \mathrm{~N}$ values change with latitude, probably related to denitrification process in 270 reduced oxygen conditions (Ménard et al. 2007, Lorrain et al. 2015) or diazotrophy in highly 271 oligotrophic areas (Houssard et al. 2017). In the tropical Atlantic Ocean, denitrification occurs 272 in the Caribbean Sea (Gruber and Sarmiento 1997) and upwelling occurs on the African coast, 273 suggesting possible baseline differences between the eastern and western Atlantic Ocean. 274 However, in the Gulf of Guinea, we assumed that the isotopic baseline is similar for these two 275 co-occurring tunas as fishing date and longitude had no effect on tuna isotopic values in our 276 study. BET and YFT are closely related (same genus; Dickson 1996), and because selected 277 individuals were at similar maturity stage and of similar length, we presume that differences 278 in $\delta^{15} \mathrm{~N}$ values did not resulted from physiological specificities. We concluded that higher $279 \delta^{15} \mathrm{~N}$ values for BET indicate its slightly higher trophic position than YFT (difference of ca. $2801.1 \%$ ), with less than one trophic level between the two species (i.e. difference $<3.4 \%$; Post 281 2002). Olson et al. (2016) obtained a smaller difference between the two species in the same 
282 region (i.e. $0.5 \%$ ) due to higher $\delta^{15} \mathrm{~N}$ values for YFT in the past $(12.2 \pm 1.0 \%$ in $2000-2004$ 283 vs. $11.7 \pm 0.9 \%$ here in 2013-2014). Regardless of possible fish length differences between 284 studies (no length effect detected for YFT here), it appears that the trophic level of YFT has 285 been decreasing over the last ten years. This suggests that either (i) YFT has a high trophic 286 plasticity related to a flexible and opportunistic diet all year round, and thus it is affected by 287 the random sampling; or (ii) as in the eastern Pacific Ocean, a decadal diet shift occurs in 288 YFT with changes in mid-trophic level communities, from large epipelagic fish $(0-200 \mathrm{~m})$ to 289 smaller mesopelagic species (200-1000 m), especially crustaceans (Olson et al. 2014). BET 290 feeds at greater depth on mesopelagic species and its trophic level has remained similar across 291 the two studies $\left(\delta^{15} \mathrm{~N}\right.$ values of $12.7 \pm 0.9 \%$ in $2000-2004$ vs. $12.8 \pm 0.6 \%$ here) suggesting a decline in the trophic level of YFT prey over the last 15 years in the epipelagic ecosystem of the Gulf of Guinea. Changes in the epipelagic communities can have a broader implication on food web balance and stability and should be monitored in the Atlantic Ocean. For example, it may increase predation on mesopelagic communities and favor competition among large predators already suspected to be less resilient to climate change than previously assumed (Lefort et al. 2015, Del Raye and Weng 2015). It might also affect tuna diving behaviour as BET seems to dive according to the food availability in the upper layers (Arrizabalaga et al. 2008) and to the thermocline depth (Houssard et al. 2017) .

Unfortunately, $\delta^{13} \mathrm{C}$ values could not be compared with bulk values of Olson et al. (2016) because lipid correction models require bulk C:N ratios (Logan et al. 2008) but changes in carbon sources (forage habitats and phytoplankton taxa) during the last decades should be explored. In the eastern Atlantic Ocean, a reduction of phytoplankton biomass might indeed propagate into the food web through a bottom-up control by the end of the $21^{\text {st }}$ century (Chust et al. 2014). Here, we detected changes in the phytoplankton taxa with an increase of 20:5n-3 proportions in tunas collected after the upwelling period started ( $\sim$ August) between $0^{\circ}$ and 
$10^{\circ} \mathrm{E}$. This change is consistent with the $20: 5 \mathrm{n}$-3-rich diatoms development favored by cool upwelling waters $\left(20-25^{\circ} \mathrm{C}\right)$ in the eastern Gulf of Guinea (Wiafe et al. 2016). FA might thus be an efficient tool to monitor forage taxa of tuna across seasons and years.

\subsection{Large overlap in the tropical tuna feeding niches}

Both SI and FA detected large overlaps $(>70 \%)$ in tuna feeding niches. Trophic position derived from $\delta^{15} \mathrm{~N}$ values was the main source of difference in tuna feeding niche (see section 4.1). The highest trophic position of BET coincides with the $\delta^{15} \mathrm{~N}$ values from the Indian Ocean: ca. $1 \%$ higher in BET than in YFT (Sardenne et al. 2016). Stomach content analyses confirm this trend and shows that BET feeds more on high trophic level prey, such as squids, than YFT (Cherel et al. 2007, Logan and Lutcavage 2013).

In contrast, $\delta^{13} \mathrm{C}$ values were similar between species, probably because phytoplankton is the major source of primary production in the pelagic systems (absence of coastal macroalgae or plants with different isotopic carbon values). Large overlap (ca. 70\%) in FA profiles indicated that BET and YFT feed on similar prey species but in different proportions. The higher MUFA proportion for BET compared to YFT (ca. $23 \pm 6 \% v s .18 \pm 7 \%$ ), especially in 18:1n-9, suggest a higher proportion of mesopelagic prey in the diet. In the tropical eastern Atlantic Ocean, MUFA- and 18:1n-9-rich copepods such as Megacalanus princeps are found between 400 and $1000 \mathrm{~m}$ deep (Teuber et al. 2014) and in the stomachs of small fish ingested by tropical tunas (Dragovich 1970). As a consequence, MUFA are also in great proportion in small fish feeding on mesopelagic copepods such as the myctophids (Saito and Murata 1998) and the cigarfish Cubiceps pauciradiatus (Young et al. 2010a), which are typical tuna prey (Bard et al. 2002, Zudaire et al. 2015). In the Indian Ocean, MUFA are also present in great proportion in tropical tunas $>100 \mathrm{~cm}$ (Sardenne et al. 2016) which have deep dive capacities and commonly swim down to $900 \mathrm{~m}$ depth (Schaefer et al. 2011). The tuna FA profiles confirmed that BET generally feed at greater depth than YFT in the Gulf of Guinea, which is 
consistent with vertical movement patterns recorded worldwide (Schaefer et al. 2009, Weng 333 et al. 2009).

334 The feeding niche overlaps observed here are larger than those observed in large tunas from 335 the Indian Ocean (no overlap for SI feeding niche and $53 \%$ for FA feeding niche in the 336 Indian Ocean using bootstrapped convex hulls; Sardenne et al. 2016) although difference in 337 metrics may explain these dissimilarities (convex hulls vs. SIBER). Convex hulls would 338 provide lower overlaps here (see Fig. 3) but SIBER was preferred to reduce metrics bias 339 related to sample size (Jackson et al. 2011).

\subsection{Ontogenic changes are limited}

Diet change during ontogeny was relatively limited in the present study for tuna ranging 64$174 \mathrm{~cm}$ FL. Only the trophic level of BET (through $\delta^{15} \mathrm{~N}$ values) increased linearly with length, but this was not associated with noticeable changes in prey taxa according to FA profiles. No ontogenic change was observed for YFT. Our sampling lacked, however, a robust representation across length classes to detect such early changes. Stomach content analyzes of YFT from the western Atlantic Ocean showed an increase in the proportion of small fish prey in individuals between 70 and $90 \mathrm{~cm}$ FL (Vaske et al. 2003). In the Pacific and Indian Oceans, diet changes with length were detected through a fast increase of $\delta^{15} \mathrm{~N}$ values for tunas between 25-55 cm FL (Graham et al. 2006, Sardenne et al. 2016). In the Indian Ocean, $\delta^{15} \mathrm{~N}$ values slowly increased with length in both BET and YFT after $60 \mathrm{~cm}(\mathrm{ca} .1 \%$ between 60 $130 \mathrm{~cm}$ ) (Ménard et al. 2007, Sardenne et al. 2016) as observed here for BET (Fig. 2a). Due to their opportunist behavior, tunas continue to feed on small prey when larger/adults (Vaske et al. 2003, Ménard et al. 2006), which have lower $\delta^{15} \mathrm{~N}$ values than larger prey (Logan and Lutcavage 2013, Ménard et al. 2014), resulting in intermediate $\delta^{15} \mathrm{~N}$ values for large tunas and limited changes in trophic level across length classes. Most FA proportions did not change with tuna length, contrary to the observations from the Indian Ocean for $18: 1 n-9$ and 22:6n-3 
357 (Sardenne et al. 2016). Future work should focus on small and large-sized tuna (20-60 cm and

$358>180 \mathrm{~cm}$ ) to investigate ontogenic changes of foraging strategies in these species.

\section{$359 \quad$ 4.4. Body condition of tropical tuna}

360 Lipids are the primary energy storage form in fish. The lipid content in an individual 361 generally indicates the energy available for vital functions and is therefore a good proxy of 362 fish global condition (Tocher 2003). Tropical tunas face limited seasonal changes in 363 comparison with their temperate counterparts and consequently store fewer lipids in muscle 364 (e.g. TLC $20 \% \mathrm{dw}$ in muscle tissue of bluefin tuna T. thynnus; Mourente et al. 2001). Yet, 365 muscle lipid content can provide valuable indication to compare general condition of tropical 366 tuna among regions. Here, the total lipid content of white muscle remained constant among 367 seasons (no influence of fishing date). Total lipid content in the Gulf of Guinea is similar to 368 TLC in the western central Pacific (TLC $\sim 6.8 \pm 4.8 \% \mathrm{dw}, \mathrm{n}=43$; Lydie Couturier, unpubl. 369 data) and higher than in the western Indian Ocean (TLC $\sim 2.3 \pm 1.1 \% \mathrm{dw}$ for both species, $370 \mathrm{n}=111$; Sardenne et al. 2016) although data from the three basins were collected across 371 different seasons. This suggests two non-exclusive assumptions: (i) BET and YFT food 372 sources are richer in the Atlantic and Pacific Oceans (in quality and/or quantity) which favors 373 energy storage in muscle, or (ii) tunas have different energy allocation strategies among world 374 regions. Tuna condition may indeed depend on prey quality, and seasonal upwelling favor the 375 biomass production from phytoplankton to small fishes which might benefit tunas 376 (Champalbert et al. 2008). Extended studies on the energy allocation strategies of tunas and 377 on lipid content in their prey in relation to the environmental condition (e.g. upwelling intensity) are required to elucidate this point and assess its ecological implications (e.g. 379 vulnerability of populations). Reproduction should be further considered as it seasonally 380 affects lipid content (Mourente et al. 2001, Zudaire et al. 2014) and any decrease in energy 381 allocation to the reproductive process might influence tuna demography. 


\subsection{Future directions}

Information about the trophic ecology of skipjack tuna Katsuwonus pelamis (over $50 \%$ of total catch in the Eastern Atlantic Ocean; ICCAT 2015) sharing schools with small BET and YFT, would improve our understanding of competition among co-occurring species and ontogenic stages. In addition, skipjack tuna and small BET and YFT occur mostly in epipelagic waters and can therefore be an interesting mid-trophic level 'sampler' in this stratum (e.g. Cherel et al. 2007). The epipelagic stratum should be more extensively monitored and the use of ecological tracers can be a powerful tool in this context.

\section{ACKNOWLEDGMENTS}

We thank the CRO-IRD-IEO team in charge of tropical tunas purse-seine fisheries monitoring in Abidjan (Ivory Coast) for their help with tunas sampling: B.D.S. Barrigah, Y.D. Irié, D.A. Gbeazere, D. Kouadio, P. Dewals and E. Chassot. We also thank the cannery "Pêche et Froid" and the European purse-seiners for providing fish. We are also very grateful to Noémie Guyot (IRD Representation, Abidjan, Ivory Coast) who kindly helped with the transport of samples between Ivory Coast and France. We thank an anonymous reviewer and the associate editor for comments and detailed suggestions that greatly improved the manuscript. This work is a contribution of the research projects ANR EMOTION and MANTUNA. It was co-funded by the French Research Institute for Sustainable Development (IRD), the Centre de Recherches Océanologiques (CRO) and the European Data Collection Framework (DCF, Reg 199/2008 and 665/2008). FS was funded by the French organization France Fillière Pêche (FFP). LC was supported by the LabexMER (ANR-10-LABX-19) and co-funded by a grant from the French government ("Investissements d'Avenir" program), by a grant from the Regional Council of Brittany (SAD program), and by the EU FP7 Marie Curie actions (PCOFUNDGA-2013-609102), through the PRESTIGE program. 


\section{REFERENCES}

407

408

409

410

411

412

413

414

415

416

417

418

419

420

421

422

423

424

425

426

427

428

429

430

431

432

433

434

435

436

437

438

439

440

441

442

443

Arrizabalaga, H., Pereira, J.G., Royer, F., Galuardi, B., Goni, N., Artetxe, I., Arregi, I., and Lutcavage, M. 2008. Bigeye tuna (Thunnus obesus) vertical movements in the Azores Islands determined with pop-up satellite archival tags. Fish. Oceanogr. 17(2): 74-83.

Aryeetey, E.B.-D. 2002. 23 Socio-economic aspects of artisanal marine fisheries management in West Africa. Large Mar. Ecosyst. 11: 323-344. doi:10.1016/S1570-0461(02)80045-3.

Bard, F.-X., Kouamé, B., and Hervé, A. 2002. Schools of large yellowfin (Thunnus albacares) concentrated by foraging on a monospecific layer of Cubiceps pauciradiatus, observed in the eastern tropical Atlantic. Col Vol Sci Ap ICCAT 54: 33-41.

Budge, S.M., Penney, S.N., and Lall, S.P. 2012. Estimating diets of Atlantic salmon (Salmo salar) using fatty acid signature analyses; validation with controlled feeding studies. Can. J. Fish. Aquat. Sci. 69(6): 1033-1046. doi:10.1139/f2012-039.

Champalbert, G.A., Kouamé, B., Pagano, M., and Marchal, E. 2008. Feeding behavior of adult Vinciguerria nimbaria (Phosichthyidae), in the tropical Atlantic $\left(0^{\circ}-4^{\circ} \mathrm{N}, 15^{\circ} \mathrm{W}\right)$. Mar. Biol. 156(1): 79. doi:10.1007/s00227-008-1067-z.

Cherel, Y., Sabatie, R., Potier, M., Marsac, F., and Ménard, F. 2007. New information from fish diets on the importance of glassy flying squid (Hyaloteuthis pelagica)(Teuthoidea: Ommastrephidae) in the epipelagic cephalopod community of the tropical Atlantic Ocean. Fish. Bull. 105(1): 147-152.

Chust, G., Allen, J.I., Bopp, L., Schrum, C., Holt, J., Tsiaras, K., Zavatarelli, M., Chifflet, M., Cannaby, H., Dadou, I., Daewel, U., Wakelin, S.L., Machu, E., Pushpadas, D., Butenschon, M., Artioli, Y., Petihakis, G., Smith, C., Garçon, V., Goubanova, K., Le Vu, B., Fach, B.A., Salihoglu, B., Clementi, E., and Irigoien, X. 2014. Biomass changes and trophic amplification of plankton in a warmer ocean. Glob. Change Biol. 20(7): 2124-2139. doi:10.1111/gcb.12562.

Dalsgaard, J., John, M.S., Kattner, G., Müller-Navarra, D., and Hagen, W. 2003. Fatty acid trophic markers in the pelagic marine environment. Adv. Mar. Biol. 46: 225-340.

Del Raye, G., and Weng, K.C. 2015. An aerobic scope-based habitat suitability index for predicting the effects of multi-dimensional climate change stressors on marine teleosts. Deep Sea Res. Part II Top. Stud. Oceanogr. 113: 280-290. doi:10.1016/j.dsr2.2015.01.014.

Diaha, N.C., Zudaire, I., Chassot, E., Barrigah, B.D., Irié, Y.D., Gbeazere, D.A., Kouadio, D., Pecoraro, C., Romeo, M.U., and Murua, H. 2016. Annual monitoring of reproductive traits of female yellowfin tuna (Thunnus albacares) in the eastern Atlantic Ocean. Collect Vol Sci Pap ICCAT 72: 534-548.

Dickson, K.A. 1996. Locomotor muscle of high-performance fishes: what do comparisons of tunas with ectothermic sister taxa reveal? Comp. Biochem. Physiol. A Physiol. 113(1): 39-49. doi:10.1016/0300-9629(95)02056-X.

Dragovich, A. 1970. The food of skipjack and yellowfin tunas in the Atlantic Ocean. Fish. Bull. 68(3): 445-460. 
Dragovich, A., and Potthoff, T. 1972. Comparative study of food of skipjack and yellowfin tunas off the coast of West Africa. Fish. Bull. 70(4): 1087-1110.

Duffy, L.M., Kuhnert, P., Pethybridge, H.R., Young, J.W., Olson, R.J., Logan, J.M., Goñi, N., Romanov, E., Allain, V., Staudinger, M., Abecassis, M., Choy, C.A., Hobday, A.J., Simier, M., Galván-Magaña, F., Potier, M., and Ménard, F. 2017. Global trophic ecology of yellowfin, bigeye, and albacore tunas: understanding predation on micronekton communities at oceanbasin scales. Deep Sea Res. Part II Top. Stud. Oceanogr. doi:10.1016/j.dsr2.2017.03.003.

France, R.L. 1995. Carbon-13 enrichment in benthic compared to planktonic algae: foodweb implications. Mar. Ecol. Prog. Ser. 124: 307-312. doi:10.3354/meps124307.

Gruber, N., and Sarmiento, J.L. 1997. Global patterns of marine nitrogen fixation and denitrification. Glob. Biogeochem. Cycles 11(2): 235-266. doi:10.1029/97GB00077.

Hobday, A.J., Arrizabalaga, H., Evans, K., Scales, K.L., Senina, I., and Weng, K.C. 2017. International collaboration and comparative research on ocean top predators under CLIOTOP. Deep Sea Res. Part II Top. Stud. Oceanogr. 140: 1-8. doi:10.1016/j.dsr2.2017.03.008.

Houssard, P., Lorrain, A., Tremblay-Boyer, L., Allain, V., Graham, B.S., Menkès, C., Pethybridge, H., Couturier, L.I.E., Point, D., Leroy, B., Receveur, A., Hunt, B.P.V., Vourey, E., Bonnet, S., Rodier, M., Raimbault, P., Feunteun, E., Kuhnert, P.M., Munaron, J.-M., Lebreton, B., Otake, T., and Letourneur, Y. 2017. Trophic position increases with thermocline depth in yellowfin and bigeye tuna across the Western and Central Pacific Ocean. Prog. Oceanogr. 154: 49-63. doi:10.1016/j.pocean.2017.04.008.

ICCAT. 2015. ICCAT stock assessments. Available from https://www.iccat.int/en/assess.htm [accessed 19 April 2017].

Iverson, S.J., Field, C., Don Bowen, W., and Blanchard, W. 2004. Quantitative fatty acid signature: a new method of estimating predator diets. Ecol. Monogr. 74(2): 211-235. doi:10.1890/024105 .

Jackson, A.L., Inger, R., Parnell, A.C., and Bearhop, S. 2011. Comparing isotopic niche widths among and within communities: SIBER-Stable Isotope Bayesian Ellipses in R. J. Anim. Ecol. 80(3): 595-602.

Kelly, J., and Scheibling, R. 2012. Fatty acids as dietary tracers in benthic food webs. Mar. Ecol. Prog. Ser. 446: 1-22. doi:10.3354/meps09559.

Layman, C.A., Araujo, M.S., Boucek, R., Hammerschlag-Peyer, C.M., Harrison, E., Jud, Z.R., Matich, P., Rosenblatt, A.E., Vaudo, J.J., and Yeager, L.A. 2012. Applying stable isotopes to examine food-web structure: an overview of analytical tools. Biol. Rev. 87(3): 545-562.

Lefort, S., Aumont, O., Bopp, L., Arsouze, T., Gehlen, M., and Maury, O. 2015. Spatial and body-size dependent response of marine pelagic communities to projected global climate change. Glob. Change Biol. 21(1): 154-164. doi:10.1111/gcb.12679.

Logan, J.M., Jardine, T.D., Miller, T.J., Bunn, S.E., Cunjak, R.A., and Lutcavage, M.E. 2008. Lipid corrections in carbon and nitrogen stable isotope analyses: comparison of chemical extraction and modelling methods. J. Anim. Ecol. 77(4): 838-846. doi:10.1111/j.13652656.2008.01394.x. 
Logan, J.M., and Lutcavage, M.E. 2013. Assessment of trophic dynamics of cephalopods and large pelagic fishes in the central North Atlantic Ocean using stable isotope analysis. Deep Sea Res. Part II Top. Stud. Oceanogr. 95: 63-73. doi:10.1016/j.dsr2.2012.07.013.

Lorrain, A., Graham, B.S., Popp, B.N., Allain, V., Olson, R.J., Hunt, B.P.V., Potier, M., Fry, B., Galván-Magaña, F., Menkes, C.E.R., Kaehler, S., and Ménard, F. 2015. Nitrogen isotopic baselines and implications for estimating foraging habitat and trophic position of yellowfin tuna in the Indian and Pacific Oceans. Deep Sea Res. Part II Top. Stud. Oceanogr. 113: 188198. doi:10.1016/j.dsr2.2014.02.003.

Madigan, D.J., Litvin, S.Y., Popp, B.N., Carlisle, A.B., Farwell, C.J., and Block, B.A. 2012. Tissue turnover rates and isotopic trophic discrimination factors in the endothermic teleost, Pacific bluefin tuna (Thunnus orientalis). PLoS ONE 7(11): e49220. doi:10.1371/journal.pone.0049220.

Ménard, F., Benivary, H.D., Bodin, N., Coffineau, N., Le Loc'h, F., Mison, T., Richard, P., and Potier, M. 2014. Stable isotope patterns in micronekton from the Mozambique Channel. Deep Sea Res. Part II Top. Stud. Oceanogr. 100: 153-163. doi:10.1016/j.dsr2.2013.10.023.

Ménard, F., Labrune, C., Shin, Y.-J., Asine, A.-S., and Bard, F.-X. 2006. Opportunistic predation in tuna: a size-based approach. Mar. Ecol. Prog. Ser. 323: 223-231.

Ménard, F., Lorrain, A., Potier, M., and Marsac, F. 2007. Isotopic evidence of distinct feeding ecologies and movement patterns in two migratory predators (yellowfin tuna and swordfish) of the western Indian Ocean. Mar. Biol. 153(2): 141-152. doi:10.1007/s00227-007-0789-7.

Ménard, F., and Marchal, E. 2003. Foraging behaviour of tuna feeding on small schooling Vinciguerria nimbaria in the surface layer of the equatorial Atlantic Ocean. Aquat. Living Resour. 16(03): 231-238. doi:10.1016/S0990-7440(03)00040-8.

Ménard, F., Stéquert, B., Rubin, A., Herrera, M., and Marchal, É. 2000. Food consumption of tuna in the Equatorial Atlantic ocean: FAD-associated versus unassociated schools. Aquat. Living Resour. 13(4): 233-240.

Mourente, G., Megina, C., and Díaz-Salvago, E. 2001. Lipids in female northern bluefin tuna (Thunnus thynnus thynnus L.) during sexual maturation. Fish Physiol. Biochem. 24(4): 351363. doi:10.1023/A:1015011609017.

Olson, R.J., Duffy, L.M., Kuhnert, P.M., Galván-Magaña, F., Bocanegra-Castillo, N., and AlatorreRamírez, V. 2014. Decadal diet shift in yellowfin tuna Thunnus albacares suggests broadscale food web changes in the eastern tropical Pacific Ocean. Mar. Ecol. Prog. Ser. 497: 157178.

Olson, R.J., Young, J.W., Ménard, F., Potier, M., Allain, V., Goñi, N., Logan, J.M., and GalvánMagaña, F. 2016. Bioenergetics, Trophic Ecology, and Niche Separation of Tunas. In Advances in Marine Biology. Edited by B.E. Curry. Academic Press. pp. 199-344. Available from http://www.sciencedirect.com/science/article/pii/S0065288116300049 [accessed 30 September 2016].

Parrish, C.C., Pethybridge, H., Young, J.W., and Nichols, P.D. 2015. Spatial variation in fatty acid trophic markers in albacore tuna from the southwestern Pacific Ocean-A potential 'tropicalization' signal. Deep Sea Res. Part II Top. Stud. Oceanogr. 113: 199-207. doi:10.1016/j.dsr2.2013.12.003. 
Pfennig, K.S., and Pfennig, D.W. 2009. Character Displacement: Ecological and Reproductive Responses to a Common Evolutionary Problem. Q. Rev. Biol. 84(3): 253-276. doi:10.1086/605079.

Pinnegar, J.K., and Polunin, N.V.C. 1999. Differential fractionation of $\delta^{13} \mathrm{C}$ and $\delta^{15} \mathrm{~N}$ among fish tissues: implications for the study of trophic interactions. Funct. Ecol. 13(2): 225-231.

Post, D.M., Layman, C.A., Arrington, D.A., Takimoto, G., Quattrochi, J., and Montaña, C.G. 2007. Getting to the fat of the matter: models, methods and assumptions for dealing with lipids in stable isotope analyses. Oecologia 152(1): 179-189. doi:10.1007/s00442-006-0630-x.

Robin, J.., Regost, C., Arzel, J., and Kaushik, S.. 2003. Fatty acid profile of fish following a change in dietary fatty acid source: model of fatty acid composition with a dilution hypothesis. Aquaculture 225(1-4): 283-293. doi:10.1016/S0044-8486(03)00296-5.

Saito, H., and Murata, M. 1998. Origin of the monoene fats in the lipid of midwater fishes: relationship between the lipids of myctophids and those of their prey. Mar. Ecol. Prog. Ser. 168: $21-33$.

Sardenne, F., Bodin, N., Chassot, E., Amiel, A., Fouché, E., Degroote, M., Hollanda, S., Pethybridge, H., Lebreton, B., Guillou, G., and Ménard, F. 2016. Trophic niches of sympatric tropical tuna in the Western Indian Ocean inferred by stable isotopes and neutral fatty acids. Prog. Oceanogr. 146: 75-88. doi:10.1016/j.pocean.2016.06.001.

Sardenne, F., Kraffe, E., Amiel, A., Fouché, E., Debrauwer, L., Ménard, F., and Bodin, N. 2017. Biological and environmental influence on tissue fatty acid compositions in wild tropical tunas. Comp. Biochem. Physiol. A. Mol. Integr. Physiol. 204: 17-27. doi:10.1016/j.cbpa.2016.11.007.

Sardenne, F., Ménard, F., Degroote, M., Fouché, E., Guillou, G., Lebreton, B., Hollanda, S.J., and Bodin, N. 2015. Methods of lipid-normalization for multi-tissue stable isotope analyses in tropical tuna. Rapid Commun. Mass Spectrom. 29(13): 1253-1267. doi:10.1002/rcm.7215.

Schaefer, K.M., Fuller, D.W., and Block, B.A. 2009. Vertical Movements and Habitat Utilization of Skipjack (Katsuwonus pelamis), Yellowfin (Thunnus albacares), and Bigeye (Thunnus obesus) Tunas in the Equatorial Eastern Pacific Ocean, Ascertained Through Archival Tag Data. In Tagging and Tracking of Marine Animals with Electronic Devices. Springer, Dordrecht. pp. 121-144. doi:10.1007/978-1-4020-9640-2_8.

Schaefer, K.M., Fuller, D.W., and Block, B.A. 2011. Movements, behavior, and habitat utilization of yellowfin tuna (Thunnus albacares) in the Pacific Ocean off Baja California, Mexico, determined from archival tag data analyses, including unscented Kalman filtering. Fish. Res. 112(1-2): 22-37. doi:10.1016/j.fishres.2011.08.006.

Teffer, A.K., Staudinger, M.D., and Juanes, F. 2015. Trophic niche overlap among dolphinfish and cooccurring tunas near the northern edge of their range in the western North Atlantic. Mar. Biol. 162(9): 1823-1840. doi:10.1007/s00227-015-2715-8.

Teuber, L., Schukat, A., Hagen, W., and Auel, H. 2014. Trophic interactions and life strategies of epito bathypelagic calanoid copepods in the tropical Atlantic Ocean. J. Plankton Res. 36(4): 1109-1123. doi:10.1093/plankt/fbu030. 
Tocher, D.R. 2003. Metabolism and functions of lipids and fatty acids in teleost fish. Rev. Fish. Sci. 11(2): 107-184. doi:10.1080/713610925.

Ukwe, C.N., Ibe, C.A., and Sherman, K. 2006. A sixteen-country mobilization for sustainable fisheries in the Guinea Current Large Marine Ecosystem. Ocean Coast. Manag. 49(7): 385-412. doi:10.1016/j.ocecoaman.2006.04.006.

Vander Zanden, M.J., Cabana, G., and Rasmussen, J.B. 1997. Comparing trophic position of freshwater fish calculated using stable nitrogen isotope ratios $\left(\delta^{15} \mathrm{~N}\right)$ and literature dietary data. Can. J. Fish. Aquat. Sci. 54(5): 1142-1158. doi:10.1139/f97-016.

Vaske, T., Vooren, C.M., and Lessa, R.P. 2003. Feeding strategy of yellowfin tuna (Thunnus albacares), and wahoo (Acanthocybium solandri) in the Saint Peter and Saint Paul Archipelago, Brazil. Bol. Inst. Pesca São Paulo 29: 173-181.

Weng, K.C., Stokesbury, M.J.W., Boustany, A.M., Seitz, A.C., Teo, S.L.H., Miller, S.K., and Block, B.A. 2009. Habitat and behaviour of yellowfin tuna Thunnus albacares in the Gulf of Mexico determined using pop up satellite archival tags. J. Fish Biol. 74(7): 1434-1449.

Wiafe, G., Dovlo, E., and Agyekum, K. 2016. Comparative productivity and biomass yields of the Guinea Current LME. Environ. Dev. 17: 93-104. doi:10.1016/j.envdev.2015.07.001.

Young, J.W., Guest, M.A., Lansdell, M., Phleger, C.F., and Nichols, P.D. 2010a. Discrimination of prey species of juvenile swordfish Xiphias gladius (Linnaeus, 1758) using signature fatty acid analyses. Prog. Oceanogr. 86(1-2): 139-151. doi:10.1016/j.pocean.2010.04.028.

Young, J.W., Lansdell, M.J., Campbell, R.A., Cooper, S.P., Juanes, F., and Guest, M.A. 2010 b. Feeding ecology and niche segregation in oceanic top predators off eastern Australia. Mar. Biol. 157(11): 2347-2368. doi:10.1007/s00227-010-1500-y.

Zudaire, I., Murua, H., Grande, M., Goñi, N., Potier, M., Ménard, F., Chassot, E., and Bodin, N. 2015. Variations in the diet and stable isotope ratios during the ovarian development of female yellowfin tuna (Thunnus albacares) in the Western Indian Ocean. Mar. Biol.: 1-15. doi:10.1007/s00227-015-2763-0.

Zudaire, I., Murua, H., Grande, M., Pernet, F., and Bodin, N. 2014. Accumulation and mobilization of lipids in relation to reproduction of yellowfin tuna (Thunnus albacares) in the Western Indian Ocean. Fish. Res. 160: 50-59. doi:10.1016/j.fishres.2013.12.010. 
Fig. 1. Location of bigeye (BET; $n=45)$ and yellowfin tuna (YFT; $n=50$ ) caught by purseseiners in the Gulf of Guinea between July 2013 and September 2014. Major seasonal upwelling (grey area) develops in boreal summer (July-September).

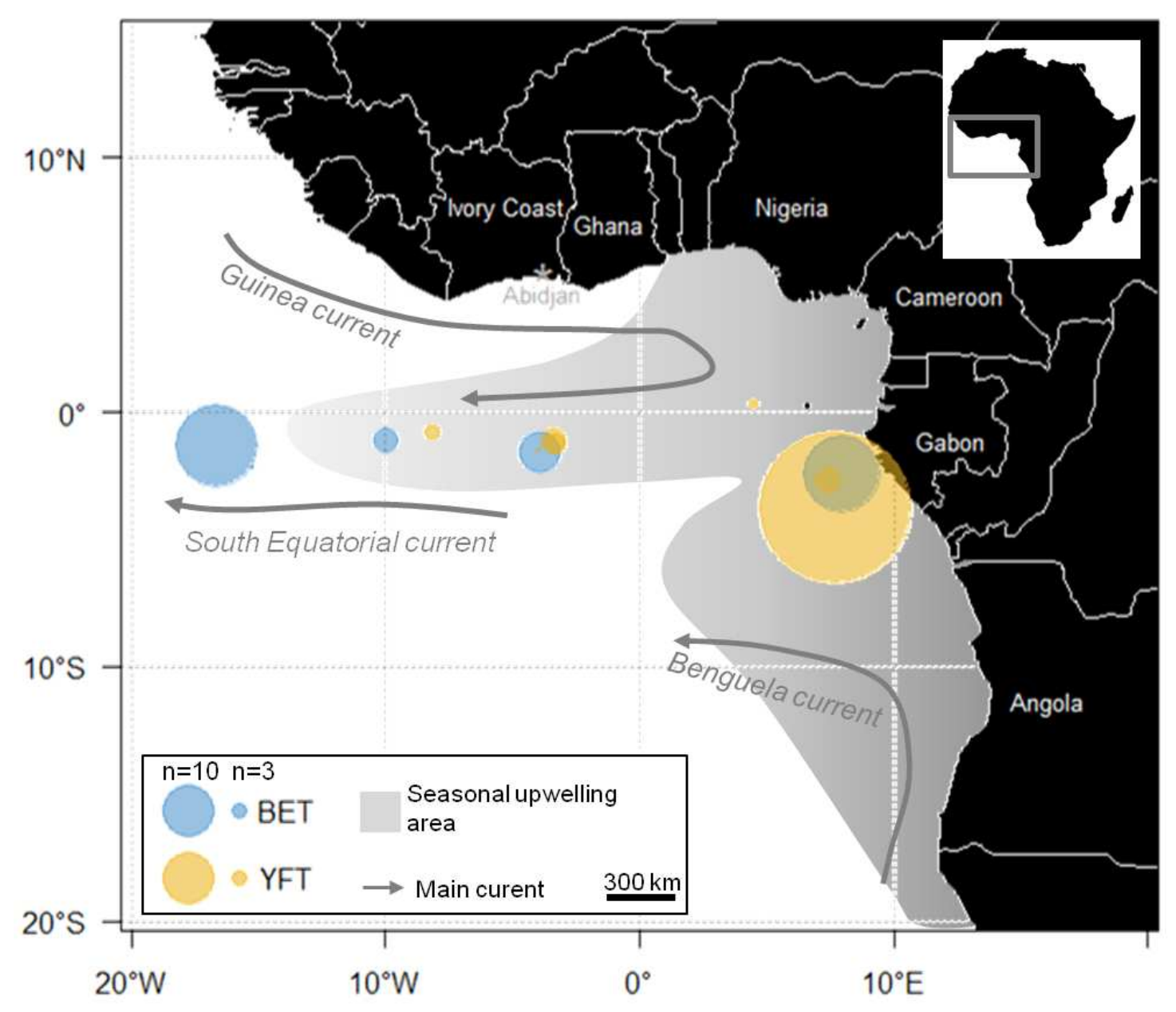


Fig. 2. Length influence on (a) nitrogen stable isotopic values $\left(\delta^{15} \mathrm{~N}\right)$, (b) carbon stable isotopic values $\left(\delta^{13} \mathrm{C}\right)$ and (c) total lipid content (TLC) in muscle tissue of bigeye (BET) and yellowfin tuna (YFT) collected from the Gulf of Guinea. Linear regressions with confidence intervals are plotted when the relationship is significant.
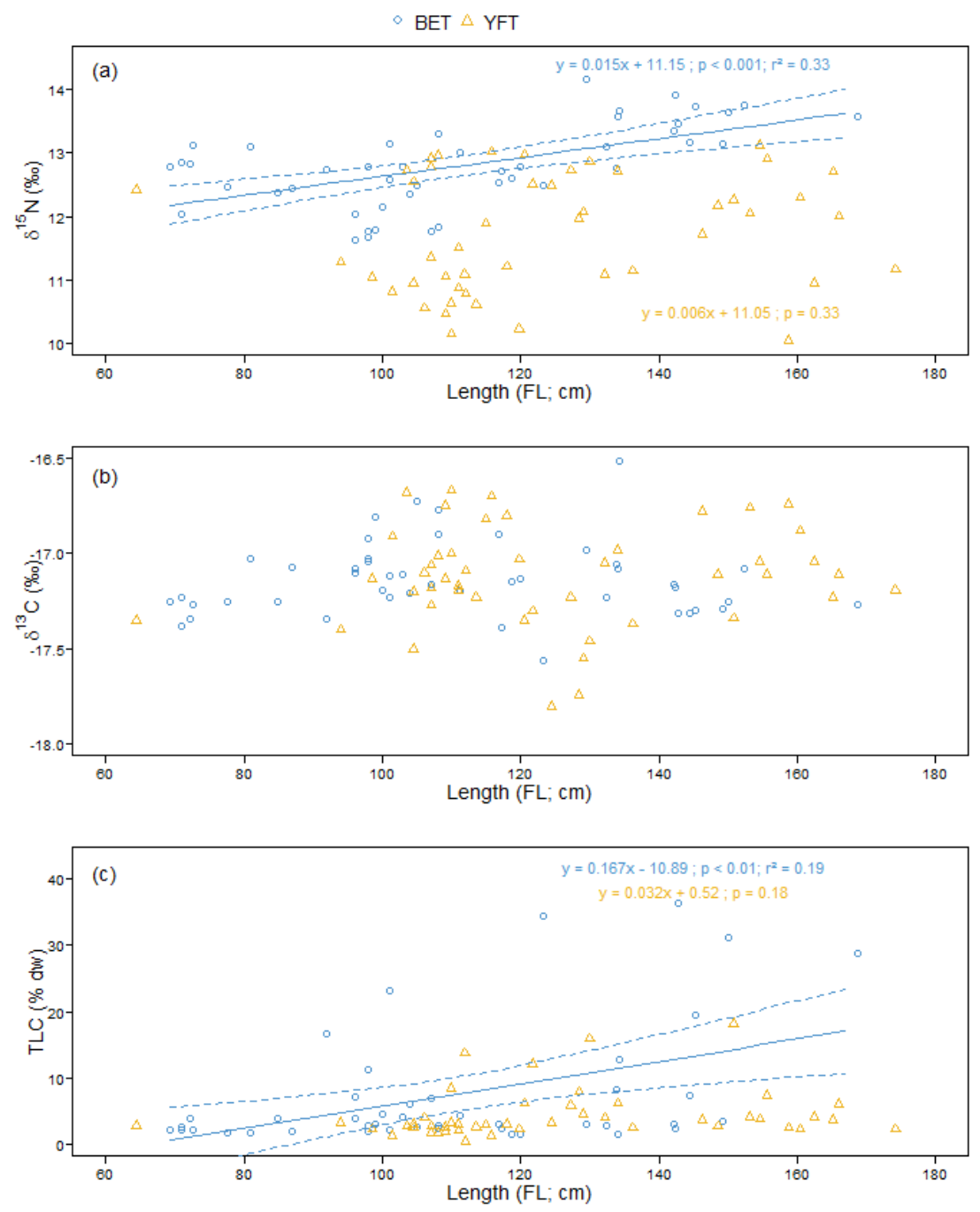
Fig. 3. Length influence on proportions of common fatty acids trophic markers in pelagic environment: (a) 20:5n-3, (b) 20:4n-6, (c) 18:1n-9 and (d) 22:6n-3, in the liver tissue of bigeye (BET) and yellowfin tuna (YFT) collected from the Gulf of Guinea. Simple linear regressions with confidence intervals are plotted when length influence is detected. The black regression in (b) is adjusted on both BET and YFT data (similar length influence for BET \& YFT).
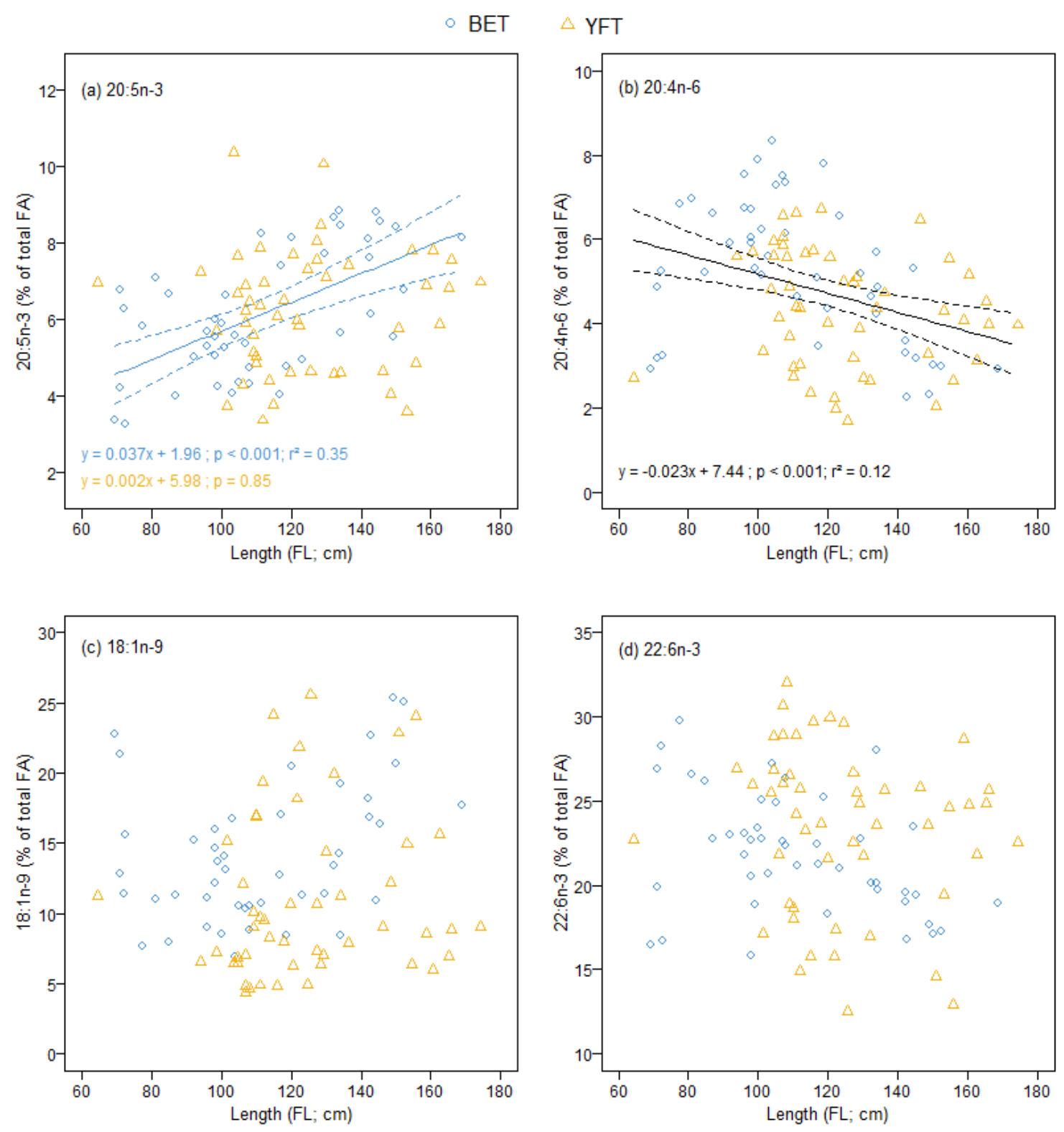
Fig. 4. Longitude influence on the three most affected fatty acids according to PCA: (a) 20:5n-3, (b) 20:4n-3 and (c) 20:4n-6, in liver tissue of bigeye (BET) and yellowfin tuna (YFT) collected from the Gulf of Guinea. Linear regressions with confidence interval are adjusted on both BET and YFT data (no species difference) (a \& b) and for BET only (c). The intensity of the grey in background indicates the seasonal upwelling influence.

- BET $\triangle$ YFT
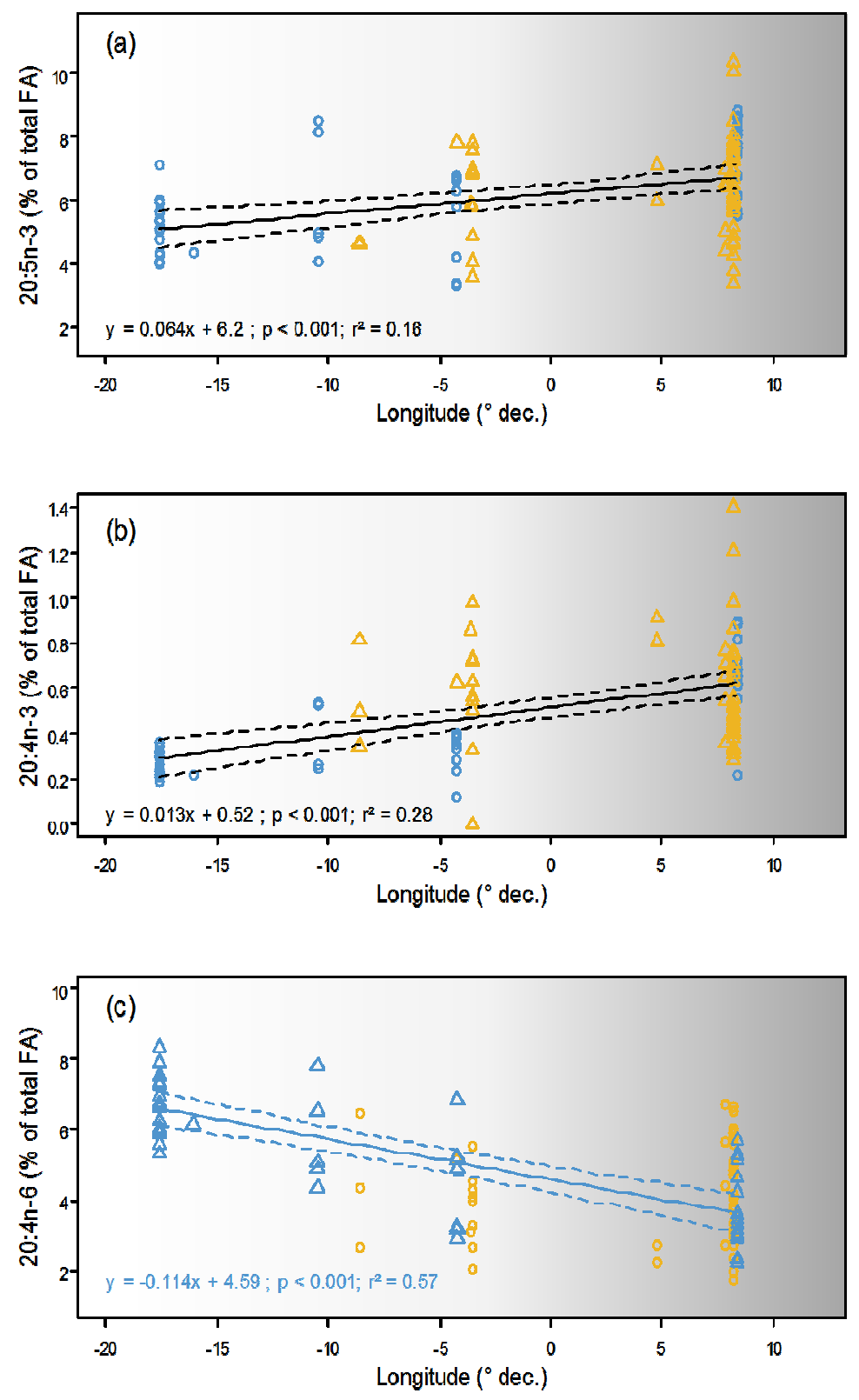
Fig. 5. Feeding niches of bigeye (BET; $n=45$ ) and yellowfin tuna (YFT; $n=50$ ) from the Gulf of Guinea using SIBER on (a) $\delta^{13} \mathrm{C}$ and $\delta^{15} \mathrm{~N}$ values of muscle, and on (b) Principal component analyze (PCA) dimensions of fatty acids (FA) profiles of liver. FA most influential in PCA $\left(\cos ^{2}>0.35\right)$ are superimposed. Ellipses areas contain $95 \%$ of the data; Boxes represent the credible intervals (95, 75 and 50\%) for the Bayesian standard ellipses areas and their overlaps (in green).
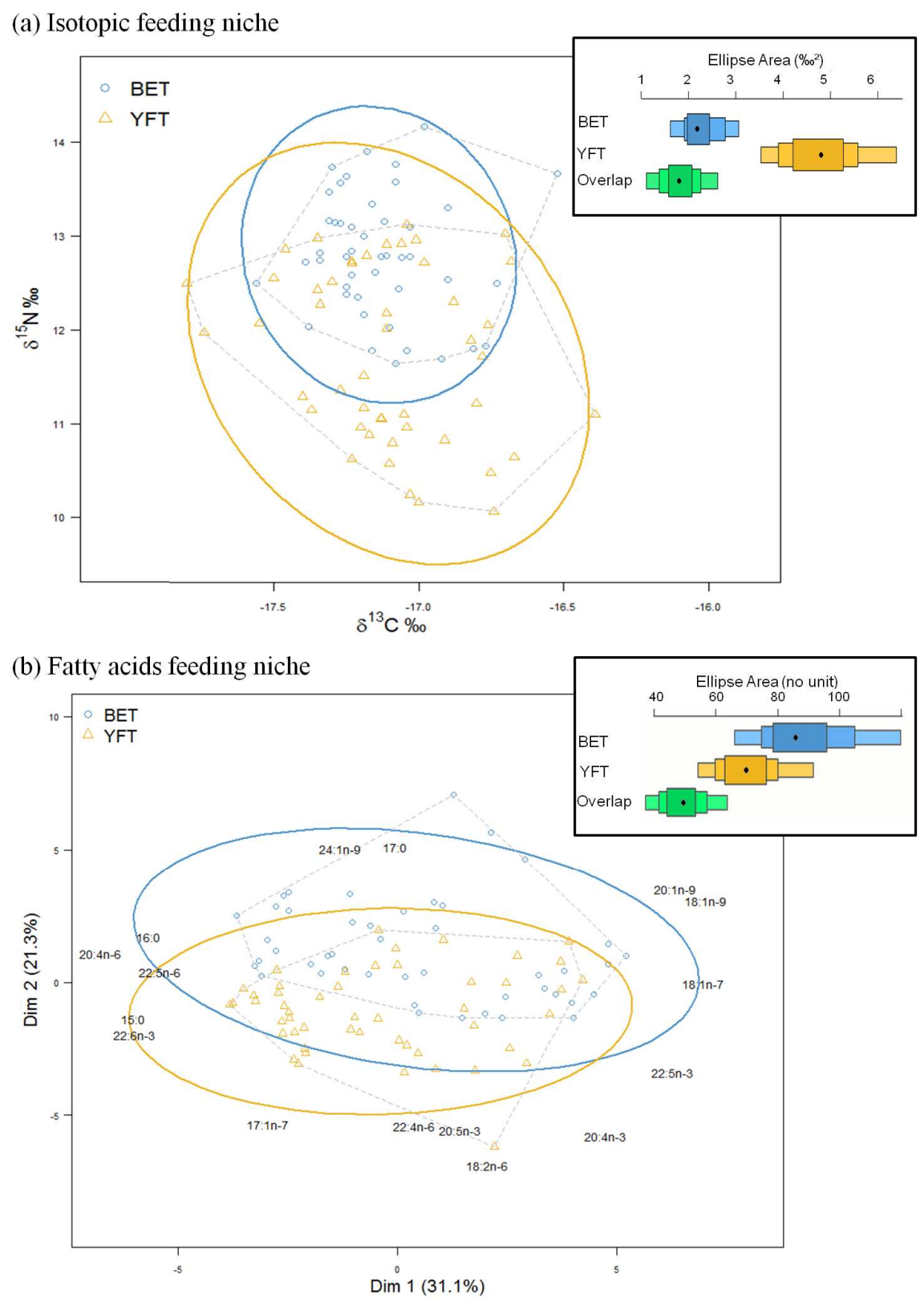
Table 1. Characteristics of fish, stable isotopes $\left(\delta^{13} \mathrm{C}\right.$ and $\delta^{15} \mathrm{~N}$ values in \%o) and total lipid content (TLC in \% dry weigh) of muscle and fatty acid (FA) distribution (in \% of total FA) of liver for bigeye (BET) and yellowfin tuna (YFT) from the Gulf of Guinea. Data are mean \pm SD. $n$ denotes sample numbers analyzed. * denotes significant differences between BET and YFT (post-hoc t-tests for stable isotopes and TLC and Wilcoxon tests for fatty acids; $\mathrm{p}<0.05)$. SFA: Saturated FA; MUFA: Mono-unsaturated FA; PUFA: Poly-unsaturated FA.

\begin{tabular}{|c|c|c|c|}
\hline & BET & YFT & \\
\hline Size (cm FL) & $111.3 \pm 25.8$ & $124.6 \pm 22.6$ & \\
\hline Sex ratio $\left(+: \oslash^{\lambda}\right)$ & $1: 1.05$ & $1: 1.63$ & \\
\hline \multicolumn{4}{|l|}{ Muscle } \\
\hline$n$ & 45 & 47 & \\
\hline$\delta^{13} \mathrm{C}(\% \mathrm{o})$ & $-17.1 \pm 0.2$ & $-17.1 \pm 0.3$ & \\
\hline$\delta^{15} \mathrm{~N}(\%)$ & $12.8 \pm 0.6$ & $11.7 \pm 0.9$ & $*$ \\
\hline TLC $(\% \mathrm{dw})$ & $7.6 \pm 9.3$ & $4.5 \pm 3.7$ & * \\
\hline \multicolumn{4}{|l|}{ Liver } \\
\hline$n$ & 45 & 50 & \\
\hline 14:0 & $0.8 \pm 0.2$ & $0.7 \pm 0.2$ & $*$ \\
\hline $15: 0$ & $0.6 \pm 0.2$ & $0.6 \pm 0.2$ & \\
\hline $16: 0$ & $23.3 \pm 4.1$ & $25.0 \pm 2.9$ & $*$ \\
\hline 17:0 & $2.0 \pm 0.4$ & $1.5 \pm 0.2$ & $*$ \\
\hline 18:0 & $8.7 \pm 1.2$ & $11.0 \pm 1.5$ & $*$ \\
\hline$\Sigma$ SFA & $35.5 \pm 4.7$ & $38.9 \pm 3.2$ & $*$ \\
\hline $16: 1 n-7$ & $2.4 \pm 0.7$ & $2.1 \pm 0.7$ & $*$ \\
\hline $17: 1 n-7$ & $1.0 \pm 0.3$ & $1.2 \pm 0.2$ & $*$ \\
\hline $18: 1 n-9$ & $14.1 \pm 4.8$ & $11.0 \pm 5.9$ & $*$ \\
\hline $18: 1 n-7$ & $2.7 \pm 0.8$ & $2.3 \pm 0.7$ & $*$ \\
\hline $20: 1 \mathrm{n}-9$ & $1.4 \pm 0.5$ & $0.9 \pm 0.4$ & $*$ \\
\hline $20: 1 n-7$ & $0.4 \pm 0.8$ & $0.1 \pm 0.1$ & * \\
\hline $24: 1 n-9$ & $0.8 \pm 0.6$ & $0.3 \pm 0.1$ & $*$ \\
\hline$\Sigma$ MUFA & $22.7 \pm 6.3$ & $17.9 \pm 7.0$ & $*$ \\
\hline $18: 2 n-6$ & $0.9 \pm 0.2$ & $1.0 \pm 0.2$ & $*$ \\
\hline $20: 4 n-6$ (ARA) & $5.2 \pm 1.7$ & $4.3 \pm 1.4$ & $*$ \\
\hline $22: 4 n-6$ & $0.4 \pm 0.2$ & $0.8 \pm 0.4$ & $*$ \\
\hline $22: 5 n-6$ & $1.3 \pm 0.4$ & $1.4 \pm 0.4$ & \\
\hline $20: 4 n-3$ & $0.4 \pm 0.2$ & $0.6 \pm 0.2$ & $*$ \\
\hline 20:5n-3 (EPA) & $6.1 \pm 1.6$ & $6.2 \pm 1.6$ & \\
\hline $22: 5 n-3$ & $1.7 \pm 0.9$ & $1.7 \pm 0.7$ & \\
\hline 22:6n-3 (DHA) & $21.9 \pm 3.5$ & $23.3 \pm 4.9$ & \\
\hline$\Sigma$ n-6 & $7.8 \pm 2.0$ & $7.5 \pm 1.7$ & \\
\hline$\Sigma \mathrm{n}-\mathbf{3}$ & $30.2 \pm 3.9$ & $31.8 \pm 5.9$ & \\
\hline$\Sigma$ PUFA & $38.0 \pm 4.8$ & $39.3 \pm 7.2$ & \\
\hline
\end{tabular}


Table 2. Summary of factors influencing the ecological tracers of bigeye (BET) and yellowfin tuna (YFT) from the Gulf of Guinea according to ANOVA (after an AIC-based selection, denotes the unselected factors) for stable isotopes values $\left(\delta^{13} \mathrm{C}\right.$ and $\left.\delta^{15} \mathrm{~N}\right)$ and total lipid content (TLC), and PERMANOVA (based on Bray-Curtis distance matrix and 1000 permutations) for fatty acids profile. P-values in bold denote factors with significant influence on the ecological tracers.

\begin{tabular}{|c|c|c|c|c|c|c|c|c|c|c|c|c|c|}
\hline \multirow{2}{*}{ Factors } & \multicolumn{3}{|c|}{$\delta^{13} \mathrm{C}$} & \multicolumn{3}{|c|}{$\delta^{15} \mathbf{N}$} & \multicolumn{3}{|c|}{ TLC } & \multicolumn{4}{|c|}{ FATTY ACIDS } \\
\hline & $d f$ & $\mathrm{~F}$ & $\mathrm{p}$-value & $d f$ & $\mathrm{~F}$ & p-value & $d f$ & $\mathrm{~F}$ & p-value & $d f \mathrm{I}$ & Pseudo-F & $r^{2}$ & $\mathrm{p}$-value \\
\hline Fishing longitude & 1 & 3.6 & 0.060 & 1 & 0.6 & 0.422 & - & - & - & 1 & 3.7 & 0.03 & 0.027 \\
\hline Fishing date & - & - & - & - & - & - & - & - & - & 1 & 0.3 & 0.00 & 0.757 \\
\hline Species & 1 & 3.3 & 0.071 & 1 & 55.1 & 0.000 & 1 & 5.6 & 0.020 & 1 & 10.5 & 0.10 & 0.001 \\
\hline Size & 1 & 0.4 & 0.511 & 1 & 8.8 & 0.004 & 1 & 14.4 & 0.000 & 1 & 5.0 & 0.05 & 0.013 \\
\hline Sex & - & _ & - & - & _ & _ & 1 & 7.7 & 0.007 & 1 & 0.5 & 0.00 & 0.653 \\
\hline Species*Size & 1 & 3.8 & 0.054 & _ & _ & - & 1 & 5.7 & 0.019 & 1 & 0.6 & 0.01 & 0.535 \\
\hline
\end{tabular}

